\title{
RESENHA DO LIVRO "BIOFUEL PARTNERSHIPS: FROM BATTLEGROUND TO COMMON GROUND?"
}

Link: http://www.reporterbrasil.org.br/documentos/biofuelpartnerships.pdf

\author{
Marcel Gomes*
}

Preço do petróleo em alta e preocupações ambientais são dois dos principais vetores a impulsionar a formulação de políticas públicas e a atrair investimentos para o ramo da bioenergia. Nos últimos anos, seja em países ricos ou em desenvolvimento, tem se massificado a utilização de etanol e biodiesel, principalmente nos sistemas de transporte de pessoas, como ocorre no caso brasileiro. Aqui, o advento dos motores flex incentivou a expansão do uso do combustível de cana pelos motoristas, que já se acostumaram a escolher entre o etanol e a gasolina disponíveis nas bombas.

Mas essas transformações no uso da energia não ocorrem sem causar uma série de impactos nos diversos setores envolvidos em sua produção, em especial no meio agrícola, fonte das matérias-primas processadas pelas usinas. Movimentos sociais, organizações não governamentais, imprensa e academia têm alertado que a expansão dos cultivos energéticos, a partir dos atuais modelos produtivos hegemônicos, incentiva o desmatamento, a superexploração do trabalhador e o avanço do latifúndio.

É esse último impacto, diretamente relacionado ao direito dos pequenos produtores sobre sua terra, que é tratado no pequeno livro "Biofuel Partnerships: from battleground to common ground?", ou, em tradução livre, "Parcerias no setor de biocombustíveis: do campo de batalha ao campo comum?". O trabalho, apenas em versão eletrônica e disponível no idioma inglês, foi lançado em 2012 pela ONG holandesa Cordaid e por seus parceiros internacionais, entre eles a ONG Repórter Brasil.

Ao longo de suas 42 páginas, o livro reúne seis estudos de caso de quatro países - além de Brasil, Honduras, Indonésia e Filipinas - realizados por seis organizações com experiência não apenas no campo da denúncia, mas também na análise social e econômica dos processos produtivos em que estão envolvidas. Um estudo com a discussão bibliográfica do tema, disponível na parte introdutória, é assinada pelo professor Otto Hospes, da Universidade de Wageningen, da Holanda, que possui experiência com pesquisas sociais sobre bioenergia no Brasil e na Indonésia.

Uma das conclusões do livro é que, para o bem ou para o mal, o modo de produção de um biocombustível define ou redefine o direito à propriedade rural compreendido em toda sua complexidade, de direito à terra, à água, às sementes e a seu próprio uso. Veja o exemplo indonésio, relatado na publicação pela ONG Lembaga Gemawan. Trata-se de um caso típico da produção em larga escala incentivada por 
governos e o setor empresarial. Em cenário asiático parecido com o amazônico, companhias de óleo de palma se apropriam de terras privadas, públicas ou comunais com o objetivo de implantar o cultivo de palmeiras em larga escala.

Mas a atividade afetou profundamente comunidades que vivem da agricultura familiar, como do arroz e da mandioca. O distrito de Samba, na fronteira com a Malásia, é um dos principais polos de expansão produtiva. Lá, os pequenos produtores se levantaram contra a degradação socioambiental. Aproveitando-se do fato de a cadeia produtiva da palma ser internacionalizada, conseguiram parceiros estrangeiros para ajudar na pressão contra países importadores do produto. Há algumas vitórias para relatar. A estratégia é arranhar cada vez mais a imagem internacional do país e, assim, obrigar o governo indonésio a alterar sua política pró-palma e a dar garantias às comunidades em risco.

A questão é que o agressivo modelo indonésio, cujos impactos são evidentes, tem sido substituído por outros arranjos produtivos ao redor do mundo, com efeitos mais sutis para o direito à propriedade das comunidades, ao menos no curto prazo. Nessa seara há até exemplos positivos, como os relatados pelos hondurenhos da Agroenhsa e da Funder, cujo fomento de atividades bioenergéticas ajuda a gerar renda no campo - e, com isso, ampliar as possibilidades de o pequeno produtor se apropriar de suas terras.

Mas são os aspectos negativos desses novos arranjos que chamam a atenção no caso brasileiro tratado em "Biofuel Partnerships". O capítulo sob responsabilidade da ONG Repórter Brasil lembra que a Amazônia tornou-se o mais novo foco da política de biocombustíveis do governo federal. Um dos principais marcos normativos do país na área, o Programa Nacional de Produção e Uso de Biodiesel (PNPB), advoga pela inserção de pequenos produtores de cultivos agroenergéticos na cadeia produtiva do biodiesel. No Estado do Pará, os alvos são os produtores de dendê, cujo óleo é usado na fabricação de biodiesel.

A partir de acordos firmados entre empresas do setor e governos de diversas instâncias, pequenos produtores amazônicos têm investido na lavoura de dendê, muitas vezes abdicando de cultivos alimentares, como a mandioca. A conversão é bancada por recursos públicos e privados, e os agricultores costumam receber alguma assistência técnica para que cumpram as metas de produtividade ditadas pelo futuro comprador da colheita.

A partir de visitas de campo realizadas nos novos polos paraenses de dendê, a ONG Repórter Brasil constatou uma série de dificuldades enfrentadas pelos produtores locais. Embora haja casos de razoável adaptação, muitos outros revelam as complicações demonstradas por agricultores familiares que não conseguem assimilar as regras de uma produção em ritmo industrial, com aplicação de químicos, podas e Resenha do livro "Biofuel Partnerships: from battleground to common ground?" 
colheitas padronizadas. Ao longo de texto, evidencia-se o risco de insegurança alimentar para os que fazem a conversão, e narram-se casos daqueles que, diante de dívidas e da "nova ordem produtiva", optam por vender suas propriedades para as companhias processadoras e migrar, com suas famílias, rumo às periferias das cidades.

É dessa maneira, trazendo casos empíricos e análises dos modelos produtivos e de seus efeitos sobre o direito à terra, que o livro avança até seu final. No caso brasileiro, é um alerta para o PNPB, programa que determina que as usinas comprem da agricultura familiar uma parcela da matéria-prima processada. Com isso, há o mérito de se buscar a construção de uma história para o biodiesel distinta da do etanol, que é baseada na monocultura e na superexploração do trabalho. Entretanto, ao se voltar à realidade, nota-se que há resultados opostos aos pretendidos.

Sendo uma publicação conduzida por ONGs, "Biofuel Partnerships" não se furta a dar recomendações para o setor público, às empresas e às próprias organizações da sociedade civil. Baseadas nos seis casos apresentados, as propostas buscam assegurar que os pequenos produtores garantam seu direito à terra, mantenham ou até ampliem o controle sobre o uso de sua propriedade, e sejam incluídos nas cadeias de valor em termos favoráveis.

Uma última nota. Para escreverem o livro, os autores utilizaram uma nova metodologia chamada "writeshop", cujo mérito pelo desenvolvimento é do Instituto para a Reconstrução Rural, das Filipinas. Trata-se de um processo participativo e que permite a produção de uma publicação em um curto período de tempo. Os autores reuniram-se durante cinco dias, no final de 2011, e cada um dos textos foi discutido em grupo. A tarefa contou com a mediação ativa do professor Otto Hospes, já mencionado anteriormente e a quem cabia incentivar análises consistentes, e de um editor, responsável pela qualidade e o padrão dos textos. Através de uma rápida leitura, os interessados na temática debatida em "Biofuel Partnerships" poderão avaliar se autores - e a própria metodologia - atingiram seus objetivos.

* Marcel Gomes é jornalista e coordenador do Centro de Monitoramento de Agrocombustíveis da ONG Repórter Brasil desde 2008. É bacharel em jornalismo e mestre em ciência política, títulos obtidos na Universidade de São Paulo (USP). Como repórter e editor, trabalhou para veículos de mídia brasileiros e participou da criação de projetos da imprensa alternativa. 